\title{
Localization on pig chromosome 6 of five markers: GPI, APOE, TGF $\beta 1$, ENO1 and PGD, carried by human chromosomes 1 and 19, using in situ hybridization
}

\author{
M Yerle, M Dalens, O Galman, J Gellin \\ Institut National de la Recherche Agronomique, Laboratoire de Génétique Cellulaire, \\ BP 27, 31326 Castanet-Tolosan, France \\ (Proceedings of the 9th European Colloquium on Cytogenetics of Domestic Animals; \\ Toulouse-Auzeville, 10-13 July 1990)
}

pig / molecular in situ hybridization / comparative mapping / halothane gene

\section{INTRODUCTION}

In the pig, the linkage group S-GPI-HAL-A1BG-PGD bearing the halothane gene (HAL: responsible for malignant hyperthermia (MH)) has been assigned to the p12 $\rightarrow$ q21 region of chromosome 6 by Davies et al (1988) and Chowdhary et al (1989). This region includes part of the short arm, the centromere, and part of the long arm. Using in situ hybridization combined with high-resolution chromosome banding analysis, we increased the precision of the localization of glucose phosphate isomerase (GPI) on pig chromosome 6. Then, with the objective of finding new markers around the HAL gene, we selected information from comparative mapping. GPI and 6-phosphogluconate dehydrogenase (PGD) are linked in the pig, but are located on different chromosomes in many other species, including man and mouse. GPI is situated on human chromosome 19 (q13.1 region) and PGD on human chromosome 1 (pter $\rightarrow$ p36.13 region). Thus, parts of pig chromosome 6 correspond to parts of human chromosomes 1 and 19 . We chose markers near the human GPI and PGD loci: APOE (apolipoprotein E), TGF $\beta 1$ (transforming growth factor $\beta 1$ ), ENO1 (enolase 1), in addition to GPI and PGD, to study their localization in the pig by molecular in situ hybridization.

\section{MATERIALS AND METHODS}

All the techniques used have been described elsewhere (Yerle et al, 1990a). The chromosomes were G-banded before hybridization using the GTG technique. The technique of Rønne et al (1987) was slightly modified and used to obtain 
prometaphase chromosomes with high-resolution G-banding (Yerle et al, 1991). The best metaphases were selected and photographed before hybridization. Metaphase and prometaphase chromosomes were classified according to the recommendations given by the Committee for the Standardized Karyotype of the Domestic Pig (1988).

The characteristics of the DNA probes used have been described elsewhere (Yerle et al, 1990a, b).

For each marker, a histogram showing the grain distribution on the chromosomes was produced. One of these histograms is presented in figure 1. A statistical evaluation of the number of silver grains per unit chromosome length was made using a Poisson distribution.

\section{RESULTS AND DISCUSSION}

The results, which are summarized in table I, demonstrate that the markers are situated on the long arm of pig chromosome 6 and, more precisely, GPI on band $\mathrm{q} 12$, APOE on band q21.2, TGF $\beta 1$ in the cen $\rightarrow$ q21 region, ENO1 in the q22 $\rightarrow$ $\mathrm{q} 24$ region, and $\mathrm{PGD}$ in the $\mathrm{q} 22 \rightarrow \mathrm{q} 25$ region.

Table I. Localization of GPI, APOE, ENO1, PGD and TGF $\beta 1$ on pig chromosome 6 by molecular in situ hybridization.

\begin{tabular}{|c|c|c|c|c|}
\hline Locus & $\begin{array}{l}\text { No of cells } \\
\text { analyzed }\end{array}$ & $\begin{array}{c}\text { Total no } \\
\text { of grains on } \\
\text { the chromosomes }\end{array}$ & $\begin{array}{c}\text { No of grains } \\
\text { on chromosome } 6\end{array}$ & $\begin{array}{l}\text { No of grains in } \\
\text { the precise region } \\
\text { of localization }\end{array}$ \\
\hline \multirow[t]{2}{*}{ GPI } & metaphases: 74 & & 219 & $\begin{array}{l}106(48 \%) \text { in } \\
\text { p1.1 } \rightarrow \mathrm{q} 12\end{array}$ \\
\hline & prometaphases: 67 & & 80 & $\begin{array}{l}52(65 \%) \text { in } \\
\text { cen } \rightarrow \mathrm{q} 12 \\
42(53 \%) \text { on } \\
\text { band } \mathrm{q} 12\end{array}$ \\
\hline \multirow[t]{2}{*}{ APOE } & metaphases: 158 & 914 & $112(12 \%)$ & $\begin{array}{l}48(43 \%) \text { in } \\
\text { cen } \rightarrow \text { q } 21\end{array}$ \\
\hline & prometaphases: 28 & & 42 & $\begin{array}{l}22(52 \%) \text { in } \\
\mathrm{q} 12 \rightarrow \mathrm{q} 21.2 \\
19(45 \%) \text { on } \\
\text { band } \mathrm{q} 21.2\end{array}$ \\
\hline ENO1 & metaphases: 201 & 1413 & $216(15 \%)$ & $\begin{array}{l}102(47 \%) \text { in } \\
\mathrm{q} 22 \rightarrow \mathrm{q} 24\end{array}$ \\
\hline PGD & metaphases: 75 & 714 & $181(25 \%)$ & $\begin{array}{l}96(53 \%) \text { in } \\
\mathrm{q} 22 \rightarrow \mathrm{q} 25\end{array}$ \\
\hline TGF $\beta 1$ & metaphases: 79 & 559 & $96(17 \%)$ & $\begin{array}{l}61(64 \%) \text { in } \\
\text { cen } \rightarrow \text { q21 }\end{array}$ \\
\hline
\end{tabular}

From these data, it can be concluded that pig chromosome $6 \mathrm{q}$ contains regions homologous to human chromosome 19 (region q13.1 $\rightarrow$ q13.2) and human chromosome 1 region (pter $\rightarrow$ p36.13), which in turn are homologous to regions of murine 

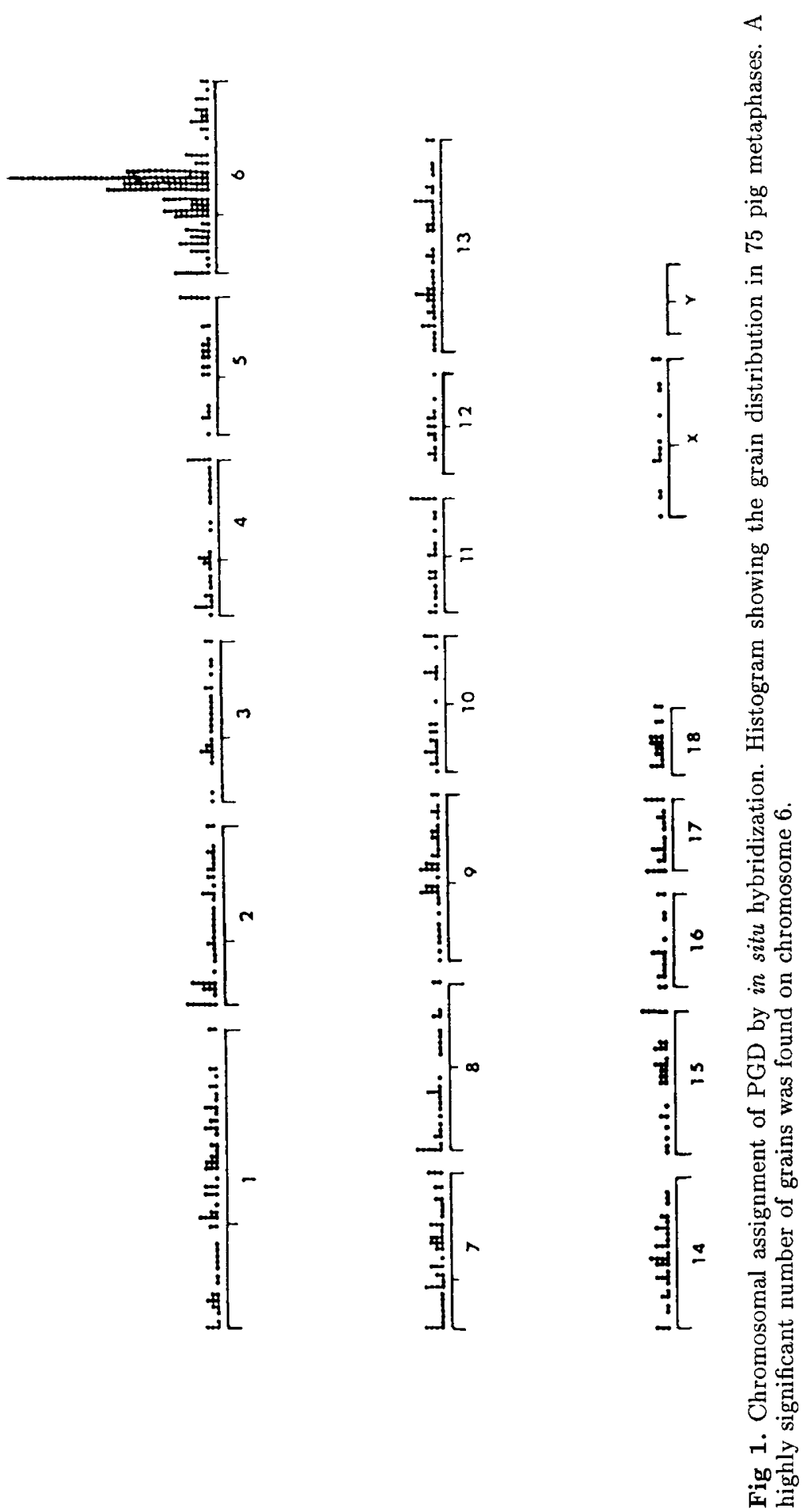
chromosomes 7 and 4, respectively (fig 2). It is of further interest that the locus responsible for malignant hyperthermia $(\mathrm{MH})$ in man has recently been mapped to the q13.1 region of HSA 19 (McCarthy et al, 1990). The assignment of the ryanodine receptor gene (RYR) to HSA 19 cen $\rightarrow$ q13.2 in man (MacLennan et al, 1990), to chromosome 6 region p11 $\rightarrow$ q21 in the pig (Harbitz et al, 1990) and to chromosome 7 in the mouse (Cavanna et al, 1990) further enhances the likelihood that the same gene is responsible for $\mathrm{MH}$ in man and pig. However, another gene, the hormone-sensitive lipase (LIPE) gene, which has been localized in the same region of human chromosome 19, could also be a good candidate for the gene responsible for malignant hyperthermia as suggested by Levitt et al (1990).

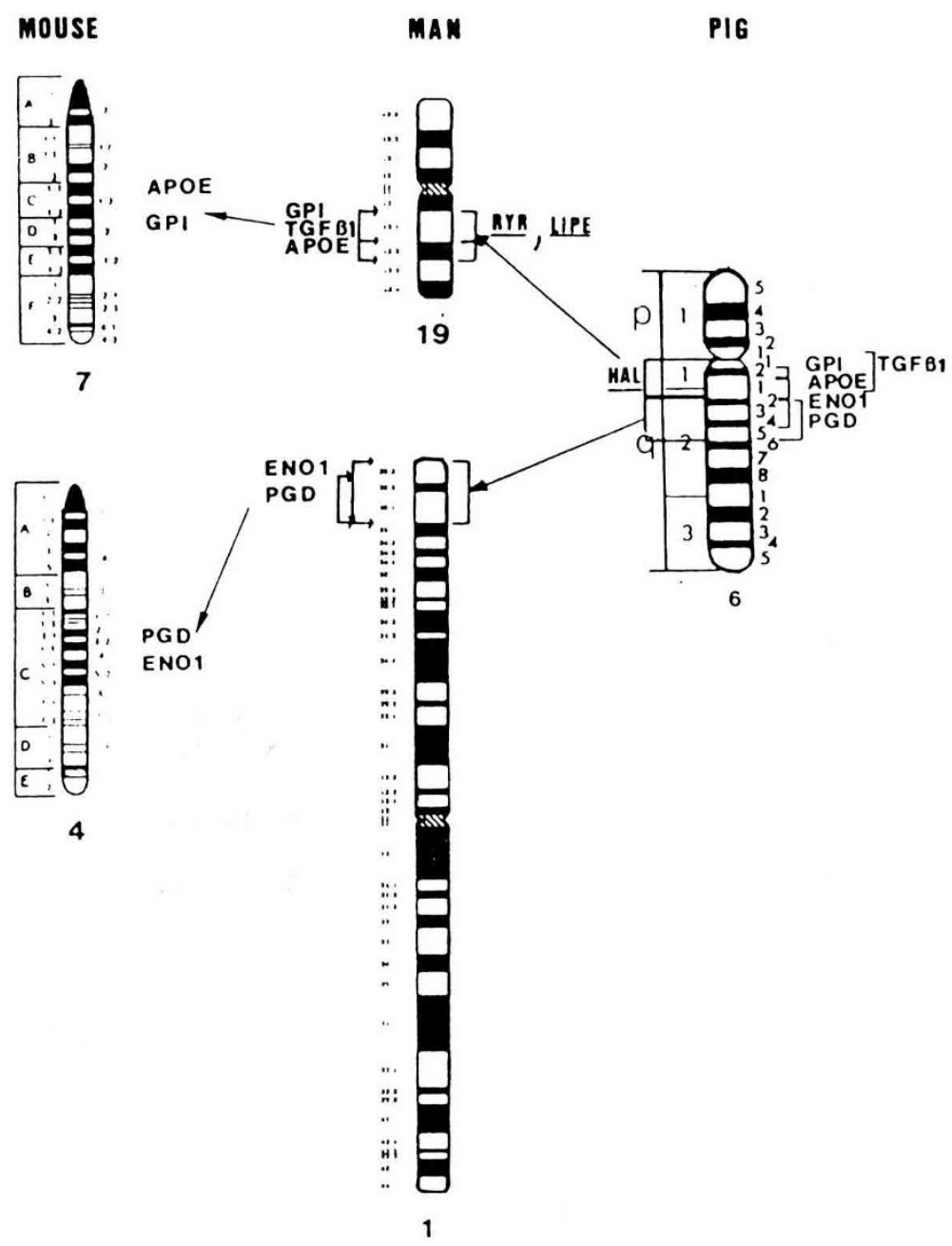

Fig 2. Comparative mapping in man, pig and mouse. Determination of homologous regions. 
The results presented here confirm that the conservation of the syntenic groups around GPI and PGD is also maintained in pigs and that malignant hyperthermia in man and pigs is likely to be the result of mutations in homologous genes.

\section{REFERENCES}

Cavanna JS, Greenfield AJ, Jonhson KJ, Marks AR, Nadal-Ginard B, Brown SDM (1990) Establishment of the mouse chromosome 7 region with homology to the myotonic dystrophy region of human chromosome 19q. Genomics 7, 12-18

Chowdhary BP, Harbitz I, Mäkinen A, Davies W, Gustavsson I (1989) Localization of the glucose phosphate isomerase gene to the p1.2 $\rightarrow \mathrm{q} 2.1$ segment of chromosome 6 in pig by in situ hybridization. Hereditas 111, 73-78

Committee for the Standardized Karyotype of the Domestic Pig (1988) Standard karyotype of the domestic pig. Hereditas 109, 151-157

Davies W, Harbitz I, Fries R, Stranzinger G, Hague JG (1988) Porcine malignant hyperthermia carrier detection and chromosomal assignment using a linked probe. Anim Genet 19, 203-212

Harbitz I, Chowdhary B, Thomsen P, Davies W, Kaufman U, Kran S, Gustavsson I, Christensen K, Hauge J (1990) Assignment of the porcine calcium release channel gene, a candidate for the malignant hyperthermia locus to the $6 \mathrm{p} 11 \rightarrow \mathrm{q} 21$ segment of chromosome 6. Genomics 8, 243-248

Levitt RC, McKusick VA, Fletcher JE, Rosenberg H (1990) Gene candidate. Letter Nature $345,297-298$

McCarthy TV, Healy JMS, Heffron JJA, Lehane M, Deufel T, Lehmann-Horn F, Farrall M, Johnson K (1990) Localization of the malignant hyperthermia susceptibility locus to human chromosome $19 \mathrm{q} 12 \rightarrow$ 13.2. Nature $343,562-563$

McLennan DH, Duff C, Zorgato F, Fujii J, Phillips M, Korneluk RG, Frodis W, Britt BA, Worton RG (1990) Ryanodine receptor gene is a candidate for predisposition to malignant hyperthermia. Nature $343,559-561$

Rønne M, Stefanova V, Di Berardino D, Poulsen BS (1987) The R-banded karyotype of the domestic pig (Sus scrofa domestica L). Hereditas 106, 219-231

Yerle M, Gellin J, Dalens M, Galman O (1990a) Localization on pig chromosome 6 of markers GPI, APOE, ENO1 carried by human chromosomes 1 and 19 using in situ hybridization. Cytogenet Cell Genet 54, 86-91

Yerle M, Archibald AL, Dalens M, Gellin J (1990b) Localization of the PGD and TGF $\beta 1$ loci to pig chromosome 6q. Anim Genet 21, 411-417

Yerle M, Galman O, Echard G (1991) The high-resolution G-T-G banding pattern of pig chromosomes. Cytogenet Cell Genet 56, 45-47 